\title{
Development of a Bacillus sphaericus tablet formulation and its evaluation as a larvicide in the biological control of Culex quinquefasciatus
}

\author{
Flávia P Morais de Medeiros/ ${ }^{+}$, Maria Alice Varjal de Melo Santos**, Leda Regis**, \\ Eugênia M Maranhão Rios*, Pedro J Rolim Neto
}

Laboratório de Tecnologia de Medicamentos, Departamento de Ciências Farmacêuticas *Laboratório de Processos Fermentativos, Departamento de Antibióticos, Universidade Federal de Pernambuco, Av. Arthur de Sá s/nº, Cidade Universitária, 50740-521

Recife, PE, Brasil **Departamento de Entomologia, Centro de Pesquisa Aggeu Magalhães-Fiocruz, Recife, PE, Brasil

This study aimed to analyze the final fermentation culture of Bacillus sphaericus 2362, standardize it and develop an active tablet formulation for use in urban mosquito breeding sites. It was performed in three phases: analysis and standardization of $a$ B. sphaericus fermented culture; physical, chemical, and biological analysis of the active powder (solubility, residual humidity, particle size, resting angle, flowing off time, compacted density, and biological activity against Culex quinquefasciatus larvae); and the development of fast-disintegrating tablets. Five formulations with differing compositions were developed and a UV protector was added to the selected formulation. The formulation products with or without UV protector, as well as the active powder caused $100 \%$ larval mortality from 1 day to 2 months after a single treatment under simulated field conditions. These results show that the UV protector does not affect the initial larvicide activity of $\mathrm{B}$. sphaericus, nor its persistence over a period of two months.

Key words: Bacillus sphaericus - Culex quinquefasciatus - larvicide - tablets

Since the sixties, when a strain of Bacillus sphaericus was discovered to have larvicidal activity against mosquito species (Kellen et al. 1965) a large number of other mosquitocidal strains have been described. A pro-toxin produced during sporulation causes fatal cellular alterations when ingested by larvae of some dipteran species (Davidson 1984, Charles 1987). This bacterium has been used to control Culex and Anopheles populations in various countries (Regis et al. 2001) replacing chemical larvicides with certain advantages, including reduction in cost and selectivity to the target populations (Elcin 1995, Federici 1995). The development of a larvicide for use in public health programmes demands selectivity - it should be active against the target species without affecting humans and other non-target populations. It should be easily produced and administered, conveniently stored, and economic (Bulla Jr et al. 1975). The development of a biological larvicide is a process similar to that of the chemical insecticides in that it aims to identify the ideal concentration and form of administration in the field. According to Couch (2000), formulation is the process used to convert a technical slurry or powder containing the active ingredient produced by the bacterium into a useful and use larvicide compatible with existing application systems. It should also ensure biological stability of the active ingredient and must have an adequate shelf life. There are two forms of administration: liquid formulations (emulsion, aqueous suspension) and solid formulations (wettable

Financial supported: CPqAM/Fiocruz, Lafepe, IPA

${ }^{+}$Corresponding author. E-mail: flavia.morais@lafepe.pe.gov.br Accepted May 2005

Received 14 June 2005 powder, powder, granules, water dispersible granules and briquets). The chemical and physical active and pre-formulation characteristics are necessary for the development of a biological insecticide (Ansel 2000). This study aimed to analyze the final fermentation culture BS1 [ $(\mathrm{a}$ product of the Empresa Pernambucana de Pesquisa Agropecuária (IPA)], standardize it according to predetermined parameters, and develop an active $B$. sphaericus powder that could be used as a rapidly disintegrating tablet for use in urban mosquito breeding sites.

\section{MATERIALS AND METHODS}

Fermentation standartization - This study utilized a fermented culture BS1, produced on scale of 10001 in the IPA laboratory, Recife, PE, using a B. sphaericus 2362 sample obtained from the Pasteur Institute, France. The presence of pathogenic microorganisms in the fermented BS1 was studied, including Streptococcus aureus, Pseudomonas aeruginosa, Candida albicans, and Escherichia coli. Other characteristics including dry weight, $\mathrm{pH}$ and viable spores were also determined. The biological activity was measured against 4th instar larvae (L4) of C. quinquefasciatus, in the Departament of Entomology, Centro de Pesquisas Aggeu Magalhães-Fiocruz (CPqAM), according to the standard World Health Organization protocol.

Characterization of the B. sphaericus active powder - The fermented BS1 was centrifuged at $3500 \mathrm{rpm}$ for 30 min. The sediment obtained was dried at $28^{\circ} \mathrm{C}$ and later pulverized and characterized. The following physical, chemical, and biological analyses of the powder were made: solubility, residual humidity (USP 23), particle size according to the Feret technique (Prista 1995, Le Hir 1997), 
resting angle, flowing off time, apparent volume and compacted density (Prista 1995), as well as the determination of viable spores and the biological activity. Standardized parameters were used for scattered powder and pulverized powder (Matthews 1982).

Development of B. sphaericus tablets - Excipients were selected according to their quantitative and qualitative characteristics to facilite direct powder compression. The formulation had an aport of $33.33 \%$ of B. sphaericus in addition to microcrystalline cellulose $102\left(\right.$ Microcel $\left.^{\circledR}\right)$, polyvinylpyrrolidone $\left(\mathrm{PVP}^{\circledR}\right)$, sodium starch glycolate $\left(\right.$ Explosol $^{\circledR}$ ), sodium croscamellose $\left(\right.$ Explocel $\left.^{\circledR}\right)$, crospovidone, magnesium stearate, and titanium dioxide.

The tablets were evaluated according to the specifications of the Brazilian Pharmacopoeia 4th edition. Five formulations were developed (Table I) on the pilot scale, and the best one was chosen to be assayed against $C$. quinquefasciatus larvae.

Assay under simulated field conditions - The initial larvicidal activity and persistence time against larvae of C. quinquefasciatus under simulated field conditions was assessed in the Department of Entomology, CPqAMFiocruz. Forty liters of well water were added to each recipient with a 461 capacity and a surface area of $0,2 \mathrm{~m}^{2}$. Nylon nets were put on the covers of the recipients allowing light incidence. The recipients were colonized with 200 C. quinquefasciatus 4th instar larvae obtained from the colony of the Department of Entomology, CPqAM. Four hundred milligrams of macerated ration was added to each recipient. One tablet containing $100 \mathrm{mg}$ of $B$. sphaericus active powder was diffused in $250 \mathrm{ml}$ of potable water, and $50 \mathrm{ml}$ of this suspension was sprayed on to the surface of each recipient. Each recipient received $20 \mathrm{mg}$ of active powder $\left(6.48 \times 10^{10}\right.$ spores/g) equivalent to $1 \mathrm{~kg} / \mathrm{ha}$. The experiments were repeated twice: two recipients were treated with product $\mathrm{A}$ (with titanium dioxide), two with product $B$ (without titanium dioxide), two with the active powder as a positive control, and two negative control non-treated recipients. Evaluation of larval mortality was performed after $48 \mathrm{~h}$ of exposure to $B$. sphaericus, however an initial observation was carried out after $24 \mathrm{~h}$ to evaluate the diffusion of the product. After this first evaluation, the recipients were colonized at weekly intervals with $10 \mathrm{egg}$ rafts of $C$. quinquefasciatus. The subsequent mortality readings were performed every seven days. The experiment was followed up during a two-month period.

\section{RESULTS AND DISCUSSION}

The fermented BS1 produced on an industrial scale should possess similar organoleptic characteristics in each batch, based on stability studies of the raw material used in the production of the B. sphaericus tablets. Color and odor, observed in four different batches were similar. Modifications of these features may have indicated contamination by other organisms. The $\mathrm{pH}$ values soon after the fermentation (TO), in the first month (T1), and in the second month (T2) can be seen in Table II. During this time the fermented culture was kept in a refrigerated chamber $\left(4^{\circ} \mathrm{C}\right)$. Pathogenecity analysis demonstrated that the second batch fermented (F-2), which had a pH around 5.0, was contaminated by $P$. aeruginosa. The other batches were not contaminated by either this or other pathogenic microorganisms such as S. aureus, C. albicans, E. coli cited in Brazilian legislation (Portaria 321 of 28/7/1997). The dry weight (Table III) predicts show concentration in the active powder. Improved efficiency can be achieved when the separation is performed in an industrial centrifuge. It is important to emphasize that the centrifugation process should guarantee the recuperation of the protein

TABLE II

$\mathrm{pH}$ data for the different batches of Bacillus sphaericus 2362 - BS1

\begin{tabular}{lccc}
\hline & \multicolumn{3}{c}{$\mathrm{pH}$} \\
\cline { 2 - 4 } Batches BS1 & $(\mathrm{T})$ & $(\mathrm{T} 1)$ & $(\mathrm{T} 2)$ \\
\hline $\mathrm{F}-1$ & 8.85 & 8.87 & 8.75 \\
$\mathrm{~F}-2$ & 5.60 & 5.50 & 5.40 \\
$\mathrm{~F}-3$ & 6.70 & 6.70 & 6.60 \\
$\mathrm{~F}-4$ & 7.36 & 7.35 & 7.30 \\
\hline
\end{tabular}

T: initial time; T1: 30 days; $\mathrm{T} 2: 60$ days

TABLE III

Dry weight (g/l) of different batches of the fermented culture BS1 of Bacillus sphaericus 2362

\begin{tabular}{lc}
\hline Batches BS1 & Dry weight $(\mathrm{g} / \mathrm{l})$ \\
\hline F - 1 & $3,15 \pm 0,14$ \\
F - 2 & $2,79 \pm 0,62$ \\
F - 3 & $3,41 \pm 1,05$ \\
F - 4 & $2,54 \pm 0,44$ \\
\hline
\end{tabular}

TABLE I

Composition of five formulations developed on the pilot scale

\begin{tabular}{lccccc}
\hline Components & $\begin{array}{c}\text { Formulation I } \\
(\%)\end{array}$ & $\begin{array}{c}\text { Formulation II } \\
(\%)\end{array}$ & $\begin{array}{c}\text { Formulation III } \\
(\%)\end{array}$ & $\begin{array}{c}\text { Formulation IV } \\
(\%)\end{array}$ & $\begin{array}{c}\text { Formulation V } \\
(\%)\end{array}$ \\
\hline Bacillus sphaericus & 33.3 & 33.3 & 33.3 & 33.3 & 33.3 \\
Microcrystalline cellulose 102 & 54.7 & 54.7 & 54.7 & 54.7 & 54.7 \\
Polyvinylpyrrolidone & 3.0 & 3.0 & 3.0 & 3.0 & 3.0 \\
Crospovidone & 7.0 & - & - & - & - \\
Sodium croscarmellose & - & - & 7.0 & 2.0 & 5.0 \\
Sodium starch glycolate & - & 7.0 & - & 2.0 & 2.0 \\
Magnesium stearate & 2.0 & 2.0 & 2.0 & 2.0 \\
\hline
\end{tabular}


complex.

The biological activity was ascertained by bioassays against $C$. quinquefasciatus larvae. Results can be seen in Table IV. The active powder potency ranged from 57 (for the contaminated F2 batch) to $102 \mathrm{ITU} / \mathrm{mg}$.

$B$. sphaericus tablets production demands a high degree of reproducibility in all fermented batches. The active powder of $B$. sphaericus was then characterized and the size of the particle was determined. Particles inferior to $5 \mu \mathrm{m}$ were observed in greater concentration and no particles larger than $44 \mu \mathrm{m}$ were found (Figure). Particle size is an important limiting factor as the mosquito larvae feeding process occurs by filtration and therefore only small particles $(<10 \mu \mathrm{m})$ are ingested. For each batch (F1, F2, F3, F4) all the particles were below this size (Figure). It was also observed that the particles have a cigar-shaped form and a uniform distribution. During the mixture and powder flow processes in the production of the tablets, the accommodation of the particles will be critical in en-

\section{TABLE IV}

Results of the bioassays expressed in $\mathrm{CL}_{50}$ of the fermented BS1 batches for Culex quinquefasciatus larvae and the potency expressed in International Toxic Units - ITU

\begin{tabular}{lccc}
\hline Batches BS1 & No. of larvae & LC $_{50}$ ppm & Potency ITU/mg \\
\hline F - 1 & 60 & 0,05 & 102 \\
F - 2 & 60 & 0,09 & 57 \\
F - 3 & 60 & 0,08 & 64 \\
F - 4 & 60 & 0,05 & 102 \\
\hline
\end{tabular}

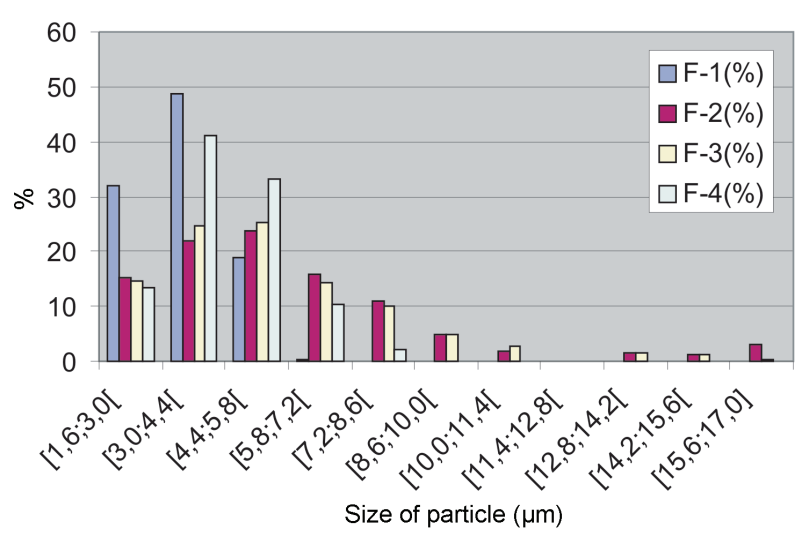

Distribution of the size of particles in the Bacillus sphaericus active powder.

abling the uniformity of the dosage.

The residual humidity (RH) of the powders, also important parameter in the production of solid forms, was then analyzed. According to the American Pharmacopoeia 23 (USP23) biological products should have RH values inferior to 5\%, however according to Prista (1995) it can be lower than $8 \%$. Results (Table V) indicated that the active powder of $B$. sphaericus obtained had an excessive water content due to the mild temperature in the drying process. It is important to reduce the $\mathrm{RH}$ in regions with a high temperature and air humidity, because inad- equate storage practice may lead to fungus development. A new process producing tablets excluding the powder drying stage is currently under research.

Table V shows results from rheology studies in the tablet-forming process. Due to a lack of technical information with which these values can be compared, these parameters were determined to better characterize the powder that had been obtained. The resting angle is an intrinsic character of powders determined by relative movement of the particles when exposed to external forces. As for the solid kinds their determination shows the easy handling especially during compression (Prista 1995). The results indicate that the active powder obtained showed excellent compressibility, however there is need to add excipient to assist fluidity and flow, as the flowing off time

\section{TABLE V}

Percentage of residual humidity of the Bacillus sphaericus powder obtained from four fermented batches (F1 to F4)

\begin{tabular}{lc}
\hline Active powder of $B$. sphaericus & Humidity (\%) \\
\hline F - 1 & 18.0 \\
F - 2 & 6.0 \\
F - 3 & 7.5 \\
F - 4 & 5.2 \\
\hline
\end{tabular}

TABLE VI

Results of the rheology study of the Bacillus sphaericus active powder

\begin{tabular}{lc}
\hline Parameters & Results \\
\hline Resting angle & $16,1^{\circ}$ \\
Time of drain & $120 \mathrm{~s}$ \\
Apparent volume & $66 \mathrm{ml}$ \\
Compact volume & $62 \mathrm{ml}$ \\
Apparent density & $0,606 \mathrm{~g} / \mathrm{ml}$ \\
Compact density & $0,645 \mathrm{~g} / \mathrm{ml}$ \\
\hline
\end{tabular}

is over $20 \mathrm{~s}$ (Table VI).

A tablet formulation based on B. sphaericus shows advantages such as dosage uniformity, stability, easy transportation, and field applicability. Five formulations with different compositions were developed and the one with the shortest disintegration time was selected. The decision for this parameter aims at easy storage, transport, and application of the product in the field whatever the breeding site type. The tablet can be applied directly on the water surface of small sites or it can be diffused in water before being pumped up, in the case of large surface water, such as for the Anopheles and some Culex breeding places. A UV physical protector (titanium dioxide) was added to this formulation since there was evidence that exposure to solar light decreases larvicidal activity. The $B$. sphaericus tablets without titanium dioxide (product A) and with titanium dioxide (product B) (Table VII) underwent physical analysis (Table VIII) before their activity and persistence were measured under simulated field conditions. In order to investigate whether 
the composition of the formulation would influence the biological activity the results of the products A and B were compared with the active powder used in the formulations. Both the formulated products and the active powder showed great initial control, with $100 \%$ lethality within $24 \mathrm{~h}$ of the application. In the following weekly evaluations $100 \%$ lethality was recorded during two months in all the treated tanks, demonstrating that during this period both the formulated products and the active powder remained in the tanks with sufficient activity to cause the death of all the larvae from the 10 egg rafts which were introduced weekly. In the control tanks the density of larvae and pupae, was checked every seven days and ranged from 35,2 to 62,8 larvae-pupae by sample $(150 \mathrm{ml}$ ladle). Throughout the two months experiment no difference in persistence of the three tested materials was detected. These results show that the use of a UV protector (titanium dioxide) does not affect the initial larvicide activity of $B$. sphaericus, nor its persistence throughout a

TABLE VII

The formulations with and without titanium dioxide

\begin{tabular}{lcc}
\hline Components & $\begin{array}{c}\text { Formulation A } \\
(\%)\end{array}$ & $\begin{array}{c}\text { Formulation B } \\
(\%)\end{array}$ \\
\hline Bacillus sphaericus & 33.3 & 33.3 \\
Microcrystalline cellulose 102 & 49.7 & 49.7 \\
Polyvinylpyrrolidone & 3 & 3 \\
Sodium croscarmellose & 7 & 7 \\
Magnesium stearate & 2 & 2 \\
Titanium dioxide & - & 5 \\
\hline
\end{tabular}

TABLE VIII

Quality control of the Bacillus sphaericus tablets. 60 tablets from each formulation (A and B) were examined for analysis of physical parameters

\begin{tabular}{lccc}
\hline Parameters & Specification & A & B \\
\hline Medium weight & $300 \mathrm{mg} \pm 5 \%$ & 290,9 & 298,5 \\
Hardness & $>5 \mathrm{kgf} / \mathrm{cm}^{2}$ & 5,0 & 5,5 \\
Friability & $<2 \%$ & 0,22 & 0,31 \\
Desintegration & $<10 \mathrm{~min}$ & 2,0 & 0,5 \\
CL $_{50}$ (Powder) & - & 0,019 & 0,019
\end{tabular}

A: tab without titanium dioxide; $\mathrm{B}$ : tab with titanium dioxide $(5 \%)$ period of two months.

\section{REFERENCES}

Ansel LFA 2000. Farmacotécnica - Formas Farmacêuticas \& Sistemas de Liberação de Fármacos, 6th ed., Premier, São Paulo, 480 pp.

Bulla Jr LA 1975. Bacteria as insect pathogens. Ann Rev Microbiol 29: 163-190.

Charles J-F 1987. Ultrastructural midgut events in culicidae larvae fed with Bacillus sphaericus 2297 spore/crystal complex. Ann Microbiol (Institut Pasteur) 138: 471-484.

Couch TL 2000. Industrial fermentation and formulation of entomopathogenic bacteria. In Entomopathogenic Bacteria: from Laboratory to Field Application, Dordrecht, The Netherland, p. 297-316.

Davidson EW 1984. Microbiology, pathology and genetics of Bacillus sphaericus: biological aspects which are important to field use. Mosq News 44: 147-151.

Elcin YM 1995. Bacillus sphaericus 2362 - Calcium alginate microcapsules for mosquito control. Enzyme Microbiol Technol 17: 587-591.

Federici BA 1995. The future of microbial insecticides as vector control agents. J Am Mosq Control Assoc 11: 260-268.

Kellen WR, Clark TB, Lindegren JE, Ho BC, Rogoff MH, Singer S 1965. Bacillus sphaericus Neide as a pathogen of mosquitoes. J Invertebr Pathol 7: 442-448.

Le Hir A 1997. Noções de Farmácia Galênica, 6th ed., Andrei, São Paulo.

Regis L, Silva-Filha MH, Nielsen-LeRoux C, Charles J-F 2001. Bacterial larvicides of dipteran disease vectors. Trends Parasitol 17: 377-380.

Mathews GA 1982. Formulations: Pesticide Application Methods, Longman, London, p. 39-56.

Portaria 321 1997. Anvisa, Diário Oficial da União; Poder Executivo, de 8 de agosto, Brasil.

Prista LN 1995. Tecnologia Farmacêutica I, II e III, 5th ed., Calouste Gulbenkian, Lisboa, 1000 pp.

USP 23 1995. The United States Pharmacopea 23, 23rd ed., USP Convention Inc., Rockville.

WHO-World Health Organization 1985. Informal consultation on the development of Bacillus sphaericus as microbial larvicide. TDR/BCV/SPHAERICUS/85.3. 1-24, Geneva. 